\title{
On the seasonal dependence of tropical lower-stratospheric temperature trends
}

\author{
Q. Fu ${ }^{1,2}$, S. Solomon ${ }^{3}$, and P. Lin $^{1}$ \\ ${ }^{1}$ Department of Atmospheric Sciences, University of Washington, Seattle, WA, USA \\ ${ }^{2}$ College of Atmospheric Sciences, Lanzhou University, Lanzhou 730000, China \\ ${ }^{3}$ Chemical Science Division, Earth System Research Laboratory, NOAA, Boulder, CO, USA
}

Received: 14 August 2009 - Published in Atmos. Chem. Phys. Discuss.: 16 October 2009

Revised: 10 March 2010 - Accepted: 11 March 2010 - Published: 18 March 2010

\begin{abstract}
This study examines the seasonality of tropical lower-stratospheric temperature trends using the Microwave Sounding Unit lower-stratospheric channel $\left(T_{4}\right)$ for 19802008. We present evidence that this seasonality is largely a response to changes in the Brewer-Dobson circulation (BDC) driven by extratropical wave forcing. We show how the tropical $T_{4}$ trend can be used as an indicator of changes in the BDC, and find that the BDC is strengthening for 19802008 in June-November related to the Southern Hemisphere (SH) and in December-February to the Northern Hemisphere (NH). In marked contrast, we find that the BDC is weakening in March-May, apparently because of a weakening of its northern cell. The novel observational evidence on the seasonal dependence of the BDC trends presented in this study has important implications for the understanding of climate change in the stratosphere as well as testing climate model simulations.
\end{abstract}

\section{Introduction}

The Brewer-Dobson circulation (BDC) is the Lagrangianmean mass circulation in the stratosphere, which consists of a meridional cell in each hemisphere with air rising across the tropical tropopause, moving poleward, and sinking to the extratropical troposphere. The BDC is driven by planetary and gravity wave breaking in the stratosphere, which acts like a "suction pump" drawing air upward from the tropics (Haynes et al., 1991; Holton et al., 1995). In an analysis of the lower-stratospheric temperatures of the microwave sounding unit (MSU) channel $4\left(T_{4}\right)$, Yulaeva et al. (1994) showed a

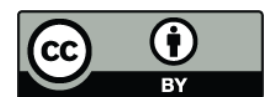

Correspondence to: $\mathrm{Q}$. Fu

(qfu@atmos.washington.edu) nearly complete compensation between temperature changes in the tropics and in the extratropics on the seasonal and interannual time scales. They interpreted these out-of-phase temperature variations between the tropics and extratropics as the signature of the variations of the BDC driven by extratropical wave forcing. Here we show that similar considerations are key to understanding decadal changes in stratospheric temperature and circulation, particularly their seasonal character.

General circulation models (GCMs) with detailed representations of the stratosphere (e.g., Sigmond et al., 2008) predict a strengthening of the BDC in recent decades in response to an increase in wave activity associated with rising greenhouse gas concentrations as well as ozone depletion (e.g. Ramaswamy et al., 1996; Rind et al., 2001; Eichelberger and Hartmann 2005; Butchart et al., 2006; Li et al., 2008). By comparing a number of middle atmosphere GCM simulations, Butchart et al. (2006) suggested that despite considerable inter-model variability, a positive trend in the tropical upward mass flux was a robust feature in the models examined, and it occurred throughout the year. On the other hand, a coupled chemistry-climate model study of Li et al. (2008) found that in the past few decades, nearly half of the tropical upward mass flux increase occurred in December-February and that both hemispheres contributed equally to these changes.

Since temperature variations in the lower stratosphere are strongly related to the residual vertical velocities (Yulaeva et al. 1994; Randel et al., 2006), the consequence of an accelerated BDC is an additional cooling of the lower tropical stratosphere but warming in the high latitudes. Observational evidence of an accelerated BDC has been shown over both the tropics (e.g., Rosenlof and Reid, 2008; Thompson and Solomon, 2009) and high latitudes (Johanson and Fu, 2007; Hu and Fu, 2009; Lin et al., 2009, as LFSW2009 hereafter) in

Published by Copernicus Publications on behalf of the European Geosciences Union. 
terms of changes in lower-stratospheric temperatures. However, there is no observational study so far that examined the seasonal dependence of the long-term changes in the BDC and their partitioning between its northern and southern cells. Such study may provide key tests of GCM predictions and improve our understanding of the climate change-induced evolution of the BDC.

The purpose of this paper is to address BDC changes using the observed seasonality of the lower-stratospheric temperature trends. We will show evidence that the seasonal dependence of observed lower-stratospheric temperature trends in the tropics is largely driven by the changes in the BDC. We will also estimate the direct radiative contribution to the cooling in the tropical lower stratosphere. Our analysis suggests that the BDC is strengthening since 1979 in June-February but weakening in March-May.

This paper is organized as follows. Section 2 describes the data used in this study. The general trend features in the lower-stratospheric temperature are presented in Sect. 3. The analysis method and results are shown in Sect. 4. The discussion and conclusions are given in Sect. 5.

\section{Data}

For the analysis of the lower-stratospheric temperature trends, we used the MSU/AMSU lower-stratospheric channel monthly brightness temperature $\left(T_{4}\right)$ gridded $\left(2.5^{\circ} \times 2.5^{\circ}\right)$ data compiled by the Remote Sensing System (RSS) (version 3.2) for 1980-2008 (Mears and Wentz, 2009). The $T_{4}$ weighting function ranges from $\sim 20 \mathrm{hPa}$ to $\sim 120 \mathrm{hPa}$ and peaks at around $60-70 \mathrm{hPa}$ (e.g., Fu and Johanson 2005), which thus well represents the lower stratosphere. Note that the $T_{4}$ may also have a contribution from the upper troposphere in the tropics. The MSU measurements extend to $82.5^{\circ} \mathrm{N}(\mathrm{S})$. Although we use the RSS $T_{4}$ data in this study, consistent results are obtained using the $T_{4}$ data from the University of Alabama at Huntsville (UAH) team (Christy et al., 2003).

To examine the ozone trend patterns, we used the monthly mean total column ozone gridded $\left(1^{\circ} \times 1.25^{\circ}\right)$ data (version 8) from the Total Ozone Mapping Spectrometer (TOMS) for 1980-2008. The National Center for Environmental Prediction/National Center for Atmospheric Research (NCEP/NCAR) reanalysis data (Kalnay et al., 1996) was used to calculate the eddy heat flux (three month mean) as an index of the strength of the BDC for a given month. The starting year in this study is 1980 to avoid the use of reanalysis data prior to 1979 (the beginning of satellite data assimilation into the reanalysis).

We examined the GCM simulations by using those performed in support of the IPCC AR4 (Meehl et al., 2007) from the World Climate Research Programme's (WCRP's) Coupled Model Intercomparison Project phase 3 (CMIP3) multi-model dataset archive. There are 22 GCM simula-

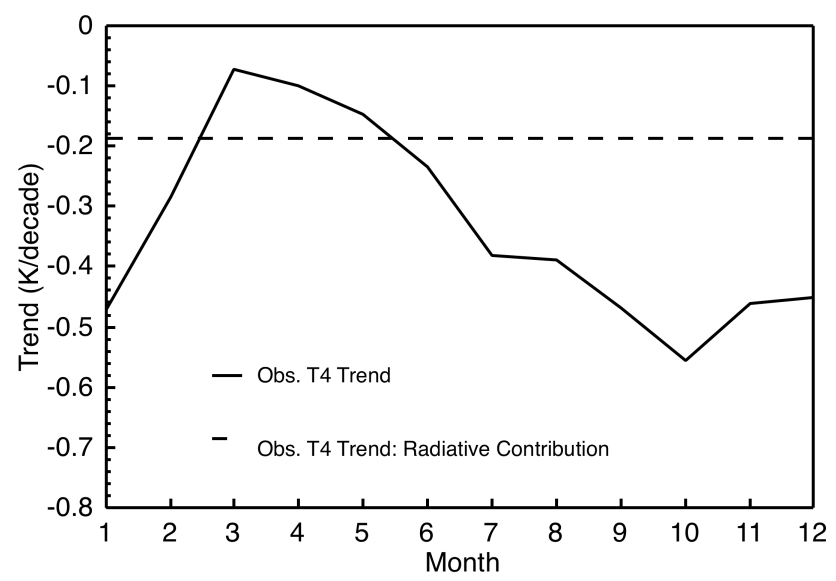

Fig. 1. MSU observed lower-stratospheric temperature $\left(T_{4}\right)$ trends in the tropics $\left(20^{\circ} \mathrm{N}-20^{\circ} \mathrm{S}\right)$ for $1980-2008$ versus month (solid lines). The dashed line indicates radiatively induced $T_{4}$ trends as derived from this study. The RSS $T_{4}$ data are used.

tions containing 48 ensemble-members, which all considered the long-lived greenhouse gas increases. Among them there are 13 models composing 28 ensembles that also considered stratospheric ozone depletion. Two sets of simulations are combined to get a full record from 1980 to 2008: one is from the 20th century experiment (20C3M), and the other is from the SRES A1B simulations that are initialized from the corresponding 20C3M ensembles at the end of 20th century. Simulated $T_{4}$ is derived by averaging the vertical profile of temperature using the MSU $T_{4}$ weighting function. In this study we considered the ensemble mean of those GCM simulations that incorporated ozone depletion.

\section{General trend features}

In this study we define the tropics as the region from $20^{\circ} \mathrm{S}$ to $20^{\circ} \mathrm{N}$ and high latitudes from $40^{\circ} \mathrm{N}(\mathrm{S})-82.5^{\circ} \mathrm{N}(\mathrm{S})$. Figure 1 shows the monthly dependence of the observed $T_{4}$ trend (solid lines) in the tropics for 1980-2008. It has a minimum cooling of $-0.07 \mathrm{~K} /$ decade in March but a large cooling of about $-0.45 \mathrm{~K} /$ decade from July to January, with an annual mean trend of $-0.33 \mathrm{~K} / \mathrm{decade}$. The dashed line indicates our estimates of the $T_{4}$ cooling due to direct radiative forcing as will be derived later based on observations.

Figure 2a shows the zonal mean $T_{4}$ trends for 1980-2008 versus month and latitude. A near-zero cooling of about $-0.01 \mathrm{~K} /$ decade occurs between $10^{\circ} \mathrm{N}-20^{\circ} \mathrm{N}$ in March. Since this near-zero trend must be a result of the combination of the direct radiative cooling induced by ozone depletion and greenhouse gas increases and the temperature changes due to vertical motion changes, it is indicative of a significant dynamic warming in March in the tropics due to decreased upward motion. This is consistent with a strong cooling in the NH high-latitudes in the same month, which is likely also 


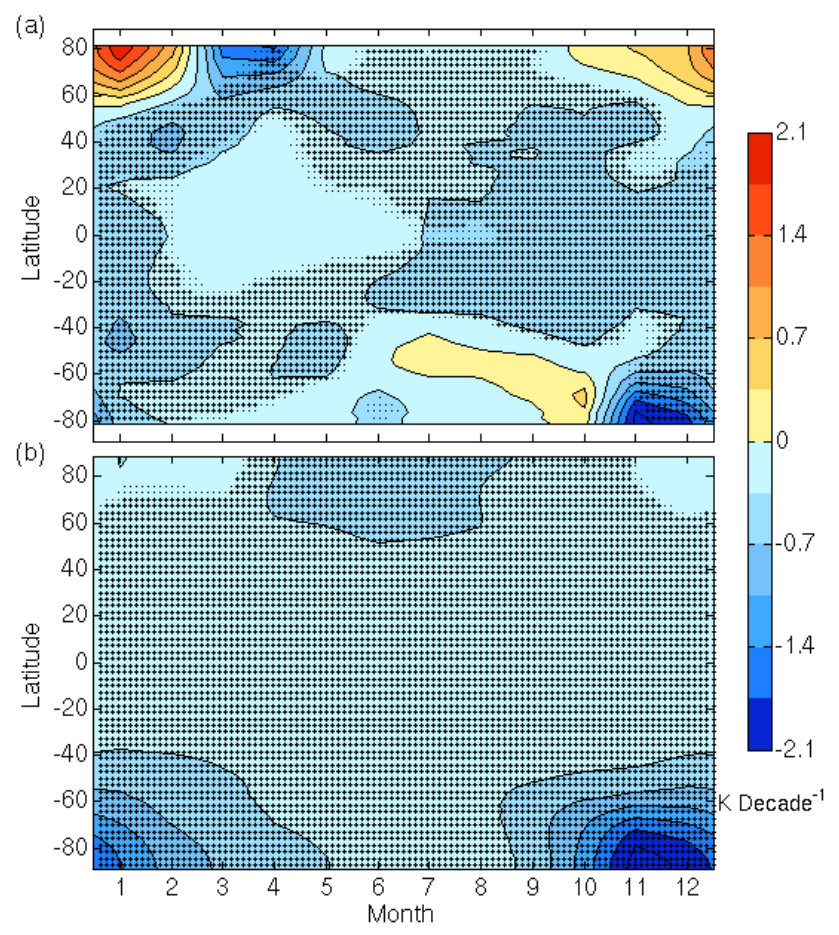

Fig. 2. Zonal mean lower-stratospheric temperature $\left(T_{4}\right)$ trends for 1980-2008 versus month and latitude from (a) MSU observations and (b) IPCC AR4 GCM simulations that consider ozone depletion. The color contour interval is $0.35 \mathrm{~K} / \mathrm{dec}$ ade. Yellow/red colors indicate positive trends and blue colors indicate negative trends. The area where trend is significant at $90 \%$ and $95 \%$ confidence levels by Student's t test is shaded by light and dark dots, respectively.

be largely dynamically driven. Figure 2(a) also shows $T_{4}$ warmings in the SH high-latitude winter/spring seasons and in the NH high-latitude winter. Since direct radiative forcing has only induced stratospheric cooling and not warming in the last three decades (e.g., Shine et al., 2003; Ramaswamy et al., 2006), these warming trends may provide a unique fingerprint of the strengthening of the BDC.

In Fig. 2a the insignificant (or near zero) $T_{4}$ trend in the tropics in the NH spring is due to the cancellation of the radiative cooling and dynamic warming. The same argument is applied to the insignificant zonal mean trend in the SH high latitudes in the SH winter and spring. The large warming with little shading region in the $\mathrm{NH}$ high latitudes in the $\mathrm{NH}$ winter is due to large natural variability as well as some cancellation of the dynamic warming by the radiative cooling there.

Figure $2 b$ is the same as Fig. 2a except from the IPCC AR4 GCM simulations that consider ozone depletion. It shows that these GCM simulations do not catch the $T_{4}$ trends associated with the change of the BDC. More discussion of the model simulations versus observations will be given in Sect. 5 .

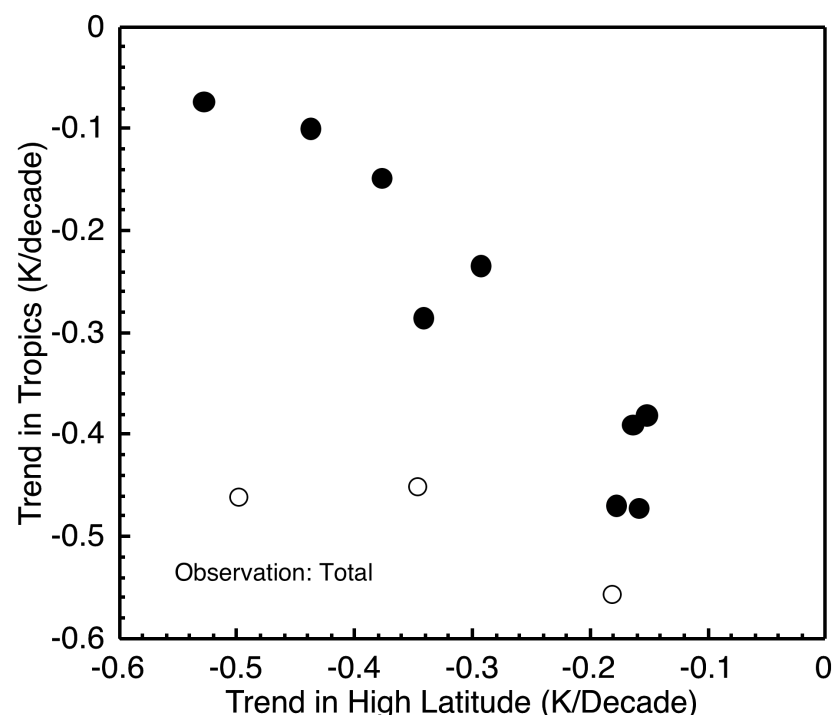

Fig. 3. MSU observed lower-stratospheric temperature $\left(T_{4}\right)$ trends in the tropics $\left(20^{\circ} \mathrm{N}-20^{\circ} \mathrm{S}\right)$ versus those in high latitudes $\left(40^{\circ} \mathrm{N}-\right.$ $82.5^{\circ} \mathrm{N}$ and $40^{\circ} \mathrm{S}-82.5^{\circ} \mathrm{S}$ ) for 12 months of the year for 1980 2008. The open circles are for October, November, and December when there is a large ozone-depletion-induced radiative cooling in Antarctica.

Figure 3 shows the MSU observed $T_{4}$ trends in the tropics $\left(20^{\circ} \mathrm{N}-20^{\circ} \mathrm{S}\right)$ versus those in high latitudes $\left(40^{\circ} \mathrm{N}-82.5^{\circ} \mathrm{N}\right.$ and $40^{\circ} \mathrm{S}-82.5^{\circ} \mathrm{S}$ ) for 12 months of the year for $1980-2008$. The solid circles are for January-September while the open circles are for October-December. The trends in tropics and high latitudes in January-September are strongly negatively correlated, with a high correlation coefficient of -0.95 . This indicates that the monthly dependence of these trends is dominated by the change of the BDC in January-September when the monthly dependence associated with the radiative forcing is relatively small. The open circles deviate from other months largely because there is a large ozone-depletion induced radiative cooling in the SH high latitudes in these months. The contribution of the change of the BDC to the $T_{4}$ trends will be quantified in Sect. 4 .

\section{Analyses and results}

In this section, we will present evidence that the seasonality of the tropical $T_{4}$ trend (solid line in Fig. 1) is largely caused by the seasonality of the changes in the BDC. We will then estimate the contribution of direct radiative cooling to the trend in tropical $T_{4}$ based on observations. For these purposes, we will first quantify the high latitude $T_{4}$ trends due to the change of the BDC and then relate them to changes linked to tropical upwelling, presumably through the downward control principle (Haynes et al., 1991; Yulaeva et al., 1994; Holton et al., 1995). 

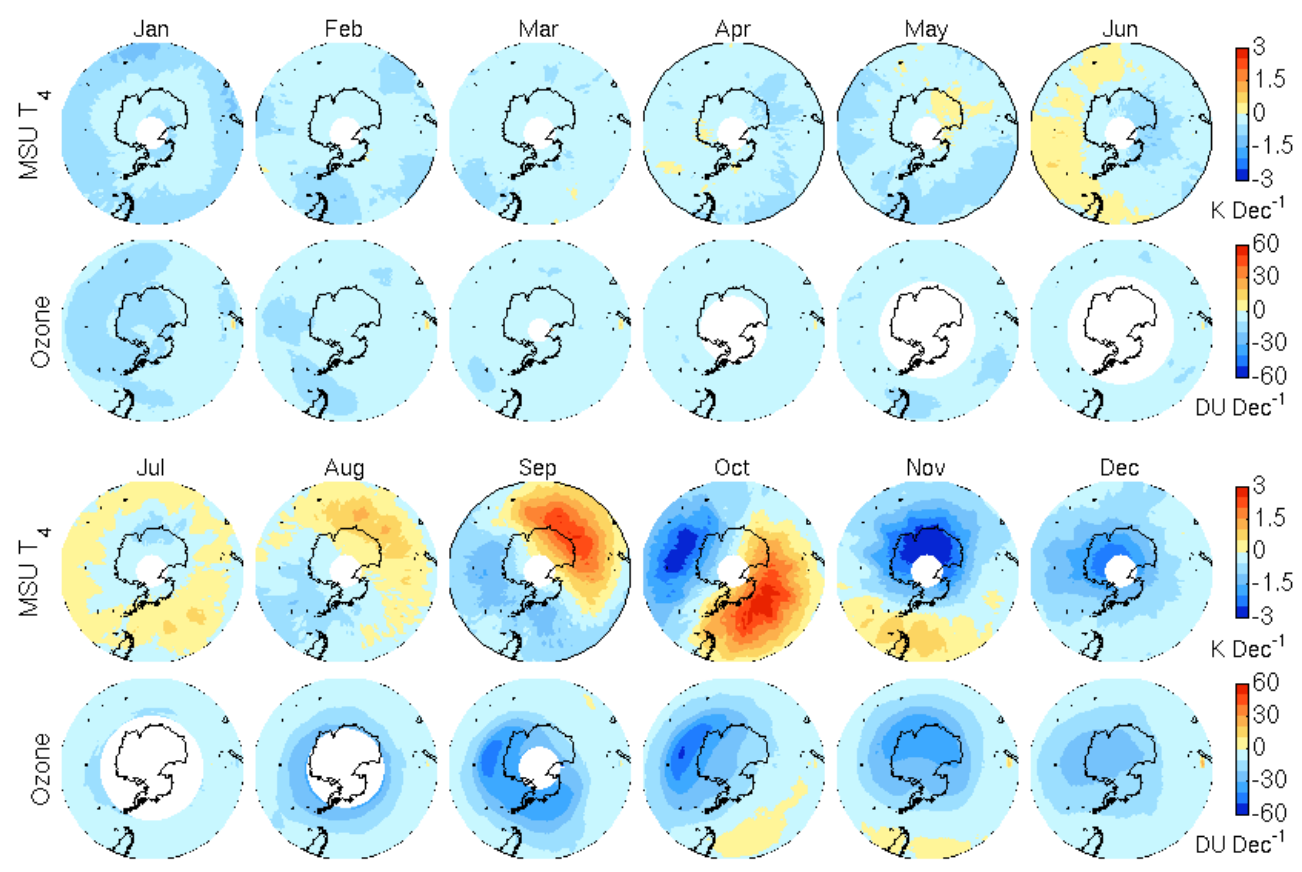

Fig. 4. Monthly trend patterns of MSU observed lower-stratospheric temperature $\left(T_{4}\right)$ and TOMS observed total ozone in SH high latitudes for 1980-2008. Yellow/red colors indicate positive trends and blue colors indicate negative trends.

LFSW2009 examined the lower-stratospheric temperature trend patterns in the winter and spring seasons in the SH high latitudes. They found that the MSU observed $T_{4}$ trend patterns can largely be attributed to a combination of ozone-depletion-induced radiative cooling, BDCacceleration-induced dynamic warming, and accompanying changes in the polar stationary planetary wavenumber- 1 . LFSW2009 used an eddy heat flux index (i.e., the threemonth mean eddy heat flux averaged over $45^{\circ} \mathrm{S}-90^{\circ} \mathrm{S}$ at $150 \mathrm{hPa}$ level) to represent the strength of the BDC, an ozone index to represent the ozone-induced radiative effect, and a phase index to represent the phase shift of the zonal wavenumber-1 component.

The eddy heat flux in the lower stratosphere, which is equivalent to the vertical component of the Eliassen-Palm (EP) flux, is often used as a proxy of the BDC (e.g., Andrews et al., 1987; Newman et al., 2001; Hu and Tung, 2002; Haklander et al., 2008; Hu and Fu, 2009; Ueyama and Wallace, 2009). In this study, a three-month mean eddy heat flux index is used following LFSW2009. Eddy activity in the previous two months is included because it can contribute to the dynamically-induced temperature anomaly in the current month due to the long radiative relaxation time in the lower stratosphere (Newman et al., 2001). In LFSW2009 the eddy heat flux at $150 \mathrm{hPa}$ was used, but here we use the vertically averaged eddy heat flux between 50 and $10 \mathrm{hPa}$ (Ueyama and Wallace, 2009). Although the correlation of eddy heat flux among $150 \mathrm{hPa}$ and upper levels is high, the vertically averaged eddy heat flux between 10 and $50 \mathrm{hPa}$ is a better rep- resentation of the amount of wave activity propagating from the troposphere to the upper stratosphere where most of these waves break. Furthermore, we consider the eddy heat flux averaged over $40^{\circ} \mathrm{S}(\mathrm{N})-90^{\circ} \mathrm{S}(\mathrm{N})$, consistent with the areas considered. Note that most eddy heat flux in the lower stratosphere is within $40-70^{\circ}$ latitude. Thus including the polar region or not has little effect on the calculated spatial-averaged eddy heat flux. The advantage of including the polar region is that the total flux over $40-90^{\circ}$ latitudes is equivalent to the convergence of the eddy heat flux over the whole area because there is no flux at the pole (Hu and Tung, 2002). We find that our results are insensitive to the eddy heat flux being averaged either over $50-80^{\circ} \mathrm{S}(\mathrm{N})$ (Ueyama and Wallace, 2009), 45-90 $\mathrm{S}(\mathrm{N})$ (LFSW2009) or $40-90^{\circ} \mathrm{S}(\mathrm{N})$.

In this study, the dynamic component of the high latitude $T_{4}$ trends due to the change of the BDC is derived as the eddy-heat-flux-congruent trend, i.e., the regression of the $T_{4}$ temperature on the eddy heat flux index times the index trend. The radiative component is then the observed total $T_{4}$ trend minus the dynamic component, averaged over $40-90^{\circ} \mathrm{S}(\mathrm{N})$. This is on the basis that although the change of the polar planetary wave in terms of magnitude/phase may affect the spatial pattern of the $T_{4}$ trend, it has little direct impact on the area-mean trend. Note that the radiatively induced $T_{4}$ trend is caused by the radiative forcing associated with both ozone depletion and increases of greenhouse gases, although the former would dominate.

We applied the above method to both SH and NH high latitudes through all months of the year (Sects. 4.1 and 4.2). 
Coupling of tropical $T_{4}$ trend and high-latitude dynamical trend is presented in Sect. 4.3 along with the discussions of the uncertainty of the results.

\subsection{Contributions to $T_{4}$ trends over $\mathrm{SH}$ high latitudes due to dynamics}

The $T_{4}$ trend patterns in the SH high latitudes in the winter and spring (June-November) exhibit a great deal of zonal asymmetry, with substantial net warming over significant parts of SH high latitudes (see Fig. 4). The small zonal mean trend (Fig. 2a), especially in September and October, represents a small residual due to the incomplete cancellation of much larger regional warming and cooling trends that are both statistically significant (Hu and Fu, 2009; LFSW2009). Consistent trend patterns in the $\mathrm{SH}$ winter and spring are also found regardless of the ending years used (e.g., 1980$1995, \ldots, 1980-2001, \ldots, 1980-2008)$, indicating that the observed trend patterns in Fig. 4 are not unduly influenced by the effect of unusual years such as 2002. Figure 4 also shows trend patterns of observed total ozone in SH high latitudes, which along with the $T_{4}$ patterns, will later be used in the discussions of our derived $T_{4}$ trends due to radiative forcing and BDC changes.

A regression of gridded monthly-mean $T_{4}$ data is performed upon the corresponding eddy heat flux index time series for each month. The regression map represents the patterns of temperature anomalies that are associated with changes in the eddy heat flux index. The attribution of the $T_{4}$ trend to changes in the BDC strength is thus obtained by multiplying the regression maps by the linear trend in the eddy heat flux index.

As an example, Fig. 5 shows the observed September $T_{4}$ trend pattern in a, the contributions to the $T_{4}$ trend due to the changes in the BDC in b, and the difference in c. The corresponding time series of the mean $T_{4}$ temperature anomalies over SH high latitudes are shown in d, e, and f, which represent the total, dynamical, and radiative components of $T_{4}$ anomalies, respectively. We see that the large dynamic warming of $0.59 \mathrm{~K} /$ decade largely cancels the radiative cooling of $-0.62 \mathrm{~K} /$ decade, leading to a near-zero $T_{4}$ total trend. Note that the slight warming in c might be related to the change of the polar planetary waves that have little direct impact on the area-mean trend. LFSW2009 showed that the September temperature change on the decadal timescale is largely driven by changes in ozone concentration and BDC.

The $T_{4}$ trend contributions due to the changing BDC and radiative forcing, averaged over $\mathrm{SH}$ high latitudes $\left(40^{\circ} \mathrm{S}-\right.$ $82.5^{\circ} \mathrm{S}$ ), versus the month of the year, are shown in Figs. 6 and 7 (dashed line), respectively. The dynamic contribution to the trend has a maximum warming of $0.63 \mathrm{~K} /$ decade in October, and is positive from May through November, as indicated in Fig. 4. It is near zero in December, January, March, and April, which is also consistent with Fig. 4. The
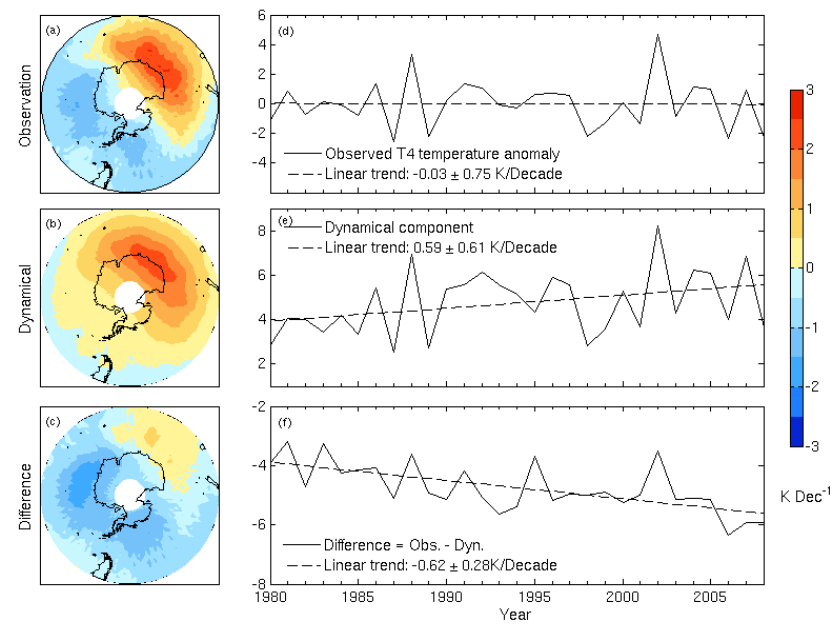

Fig. 5. (a) MSU observed lower-stratospheric temperature $\left(T_{4}\right)$ trend pattern in units of K/decade for 1980-2008 in southern hemisphere high latitudes in September. (b) $T_{4}$ trend pattern attributed to the trend of the BDC. (c) $T_{4}$ trend pattern difference between (a) and (b). (d) Time series of the observed $T_{4}$ temperature anomaly averaged over southern hemisphere high latitudes in September and its linear trend with the $95 \%$ confidence interval. (e) Time series of the $T_{4}$ temperature attributed to the variation of the BDC and its linear trend. (f) Time series of (d)-(e) and its linear trend. In (a), (b), and (c), yellow/red colors indicate positive trends and blue colors indicate negative trends.

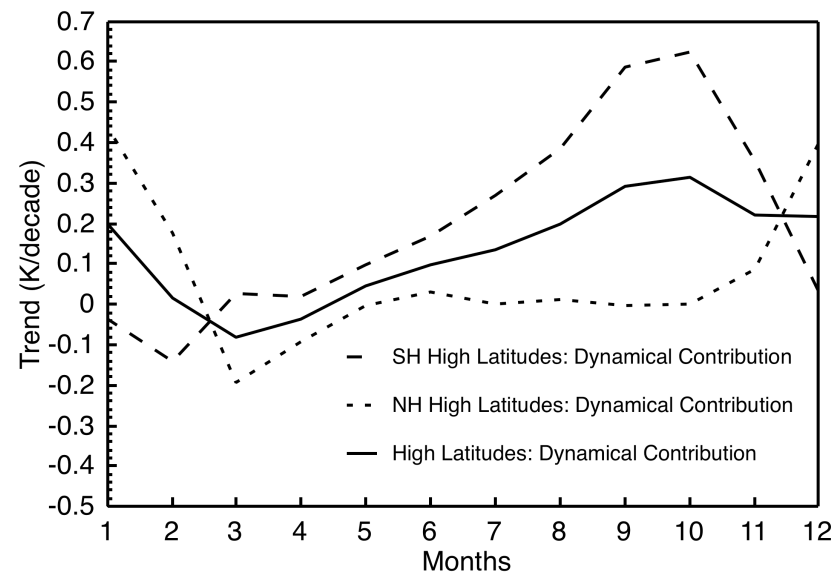

Fig. 6. MSU lower-stratospheric temperature $\left(T_{4}\right)$ trends due to the changes in the BDC in the $\mathrm{SH}$ high latitudes $\left(40^{\circ} \mathrm{S}-82.5^{\circ} \mathrm{S}\right)$ (dashed line), $\mathrm{NH}$ high latitude $\left(40^{\circ} \mathrm{N}-82.5^{\circ} \mathrm{N}\right)$ (dotted line), and the high latitudes $\left(40^{\circ} \mathrm{N}-82.5^{\circ} \mathrm{N}\right.$ and $\left.40^{\circ} \mathrm{S}-82.5^{\circ} \mathrm{S}\right)$ (solid line) for 1980-2008 versus month.

derived dynamic trend however is negative $(-0.14 \mathrm{~K} /$ decade $)$ in February.

The radiative contributions to the trends (Fig.7) have large cooling in the SH spring and early summer related to the ozone hole (see Fig. 4). The second maximum cooling in May may be explained by more ozone depletion than April 




Fig. 7. MSU lower-stratospheric temperature $\left(T_{4}\right)$ trends due to the radiative forcing in the $\mathrm{SH}$ high latitudes $\left(40^{\circ} \mathrm{S}-82.5^{\circ} \mathrm{S}\right)$ (dashed line), $\mathrm{NH}$ high latitude $\left(40^{\circ} \mathrm{N}-82.5^{\circ} \mathrm{N}\right)$ (dotted line), and the high latitudes $\left(40^{\circ} \mathrm{N}-82.5^{\circ} \mathrm{N}\right.$ and $\left.40^{\circ} \mathrm{S}-82.5^{\circ} \mathrm{S}\right)$ (solid line) for 1980 2008 versus month.

and June in the illuminated regions of the SH high latitudes (Fig. 4). But we cannot explain the minimum cooling in February when there is more ozone depletion with more solar illumination than March-May. Therefore we conclude that our method using the NCEP/NCAR reanalysis data may underestimate the radiative cooling in February and thus the dynamic cooling in this month may be an artifact. Note that the derived dynamic trend is near-zero if we substitute the radiative cooling in February with that in March or with the average of January and March. [The radiative cooling in February should not be smaller than that in March.]

\subsection{Contributions to $T_{4}$ trends over $\mathrm{NH}$ high latitudes due to dynamics}

The zonal mean trend in $\mathrm{NH}$ high latitudes (Fig. 2a) shows very strong warming during the winter, which must be driven by dynamics, i.e., adiabatic compression associated with a stronger BDC. However, the NH also displays strong zonal mean cooling in the spring (March-April). This is very unlikely to be due to ozone loss since the ozone losses in the Arctic are much smaller than in the Antarctic (see Fig. 8 versus Fig. 4). Further, tropical near-zero $T_{4}$ trend is observed in March, proving important evidence that the cooling in $\mathrm{NH}$ spring is due to a reduction in the strength of the BDC (Fig. 2). In the NH summer, since the effect of the BDC on the NH high latitudes is small (e.g., Yulaeva et al. 1994), the cooling (Fig. 2) in this season must be largely caused by direct radiative forcing.

We estimate the NH high latitude trends due to the BDC changes and radiative forcing by using the same method as in SH high latitudes. Figure 9 is the same as Fig. 5 except for NH high latitudes in December as an example. For the area-mean total $T_{4}$ trend of $-0.08 \mathrm{~K} /$ decade in December, the dynamic and radiative contributions are $0.40 \mathrm{~K} /$ decade and $-0.32 \mathrm{~K} /$ decade, respectively.

Figure 6 indicates that the dynamic warming in $\mathrm{NH}$ high latitudes (dotted line) is small from May to October. It becomes large in December $(0.40 \mathrm{~K} /$ decade $)$ and January $(0.44 \mathrm{~K} /$ decade $)$. As already noted, there is a cooling in March $(-0.20 \mathrm{~K} /$ decade), which appears to be coupled with the dynamic warming in the tropics in the same month.

Since there is no ozone hole in the NH high latitudes, we expect much less seasonal dependence of radiatively induced $T_{4}$ trends there (see dotted line in Fig. 7). The annual mean radiative cooling in the $\mathrm{NH}$ high latitude is $-0.35 \mathrm{~K} /$ decade. The minimum cooling in January, as over SH high latitude in July, is partly because of minimum solar illumination there. Figure 7 indicates more radiative cooling over NH high latitudes in February and March than in April and May. But we note a similar ozone trend with less solar illumination in February and March as compared to those in April and May (Fig. 8), suggesting that there might be an overestimate of radiative cooling, and thus an underestimate of dynamic cooling in the same amount in these two months.

The solid line in Fig. 7 shows the average of the radiatively-induced $\mathrm{SH}$ and $\mathrm{NH}$ high-latitude trends. As expected from the analysis of Fig. 2, the seasonal dependence of these trends in the first nine months of the year is relatively small.

\subsection{Coupling of tropical $T_{4}$ trend and high-latitude dynamical $T_{4}$ trend}

The contribution of the estimated high-latitude $T_{4}$ trend due to dynamics is shown in Fig. 6 (the solid line), which is the average of the dynamically-induced $\mathrm{SH}$ and $\mathrm{NH}$ highlatitude trends. This trend is normalized and shown in Fig. 10 versus month as compared with the normalized tropical $T_{4}$ trends multiplied by $(-1)$. The normalized trend is defined as $\left(x_{i}-\bar{x}\right) /\left(\sum_{i=1}^{12}\left(x_{i}-\bar{x}\right)^{2} / 12\right)^{1 / 2}$ where $x_{i}$ is the trend for a given month and $\bar{x}$ is the annual mean trend. Figure 10 indicates a nearly complete compensation between these two normalized trends. The close coupling between the tropical $T_{4}$ trend and the high-latitude dynamically induced $T_{4}$ trend can be understood as a response of the lower-stratospheric temperature to the change in the BDC driven by extratropical wave forcing. Figure 10 suggests that the seasonal dependence of the $T_{4}$ trend in the tropics is largely driven by dynamics.

We can relate the $T_{4}$ trend in the tropics (solid line in Fig. 1) to the dynamically induced $T_{4}$ trend in high latitudes (solid line in Fig. 6) by least-square fitting

$T_{4}$, Tropics $=a+b T_{4}$, High-Lat, Dynamic Contri.,

where $a$ is $-0.17 \mathrm{~K} /$ decade and $b$ is -1.2 with the correlation coefficient $(r)$ of -0.95 (see Fig.11). Equation (1) suggests a $T_{4}$ trend of $-0.17 \mathrm{~K} /$ decade in the tropics when the impact 

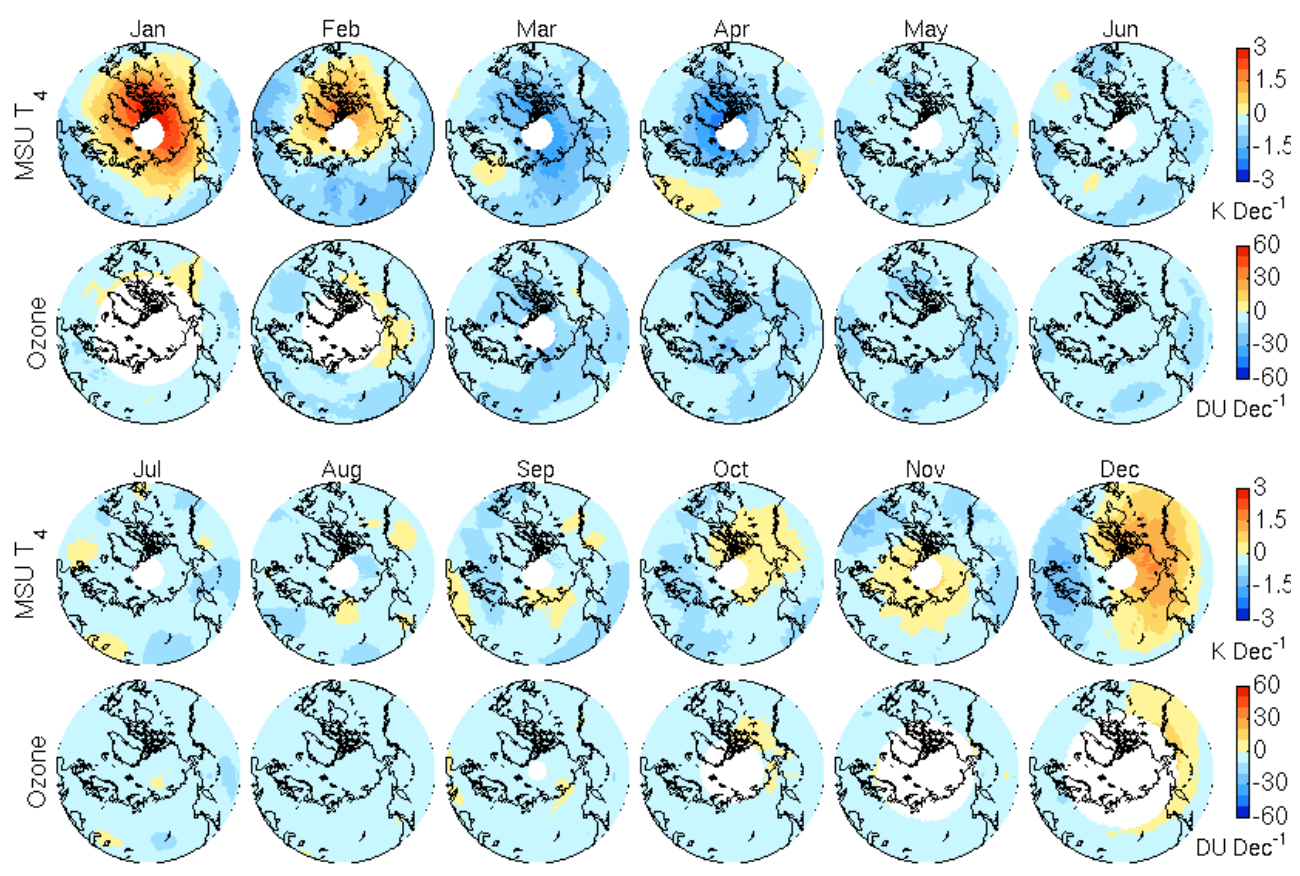

Fig. 8. Same as Fig. 4 except for NH high latitudes.
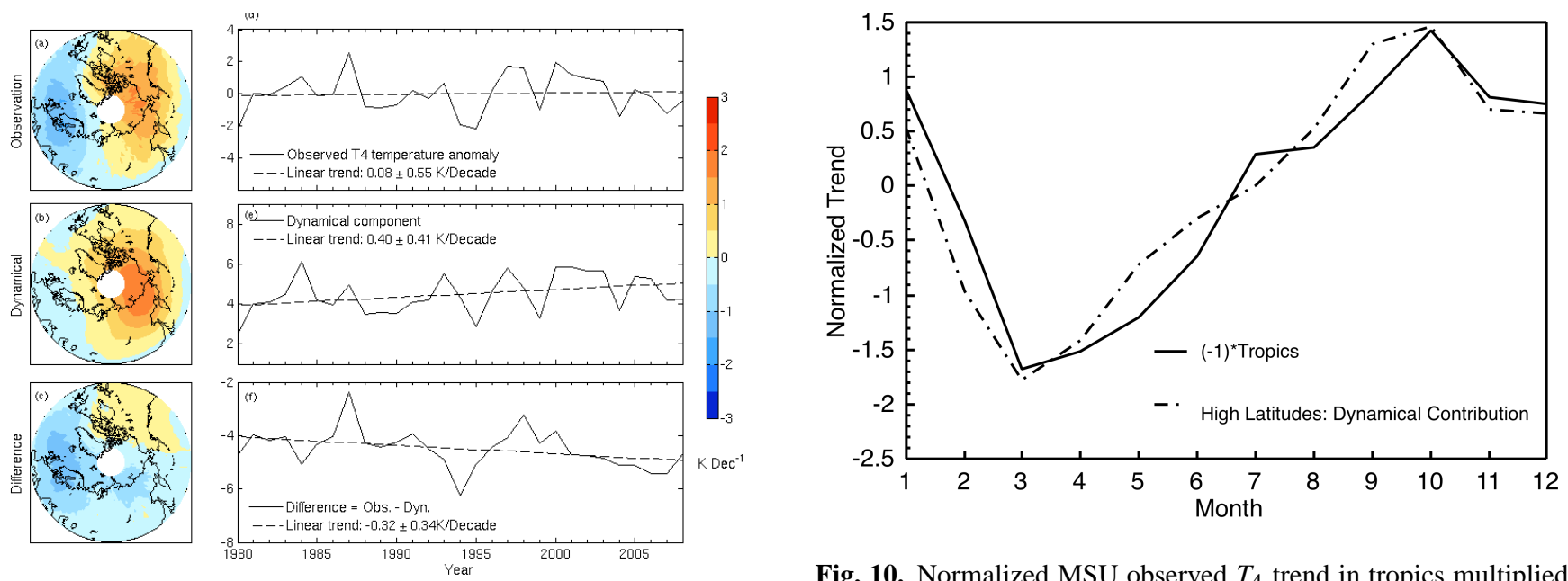

Fig. 10. Normalized MSU observed $T_{4}$ trend in tropics multiplied by $(-1)$ (solid line) and the normalized $T_{4}$ trend in high latitudes due to the changes in the BDC (dashed-dotted line) for 1980-2008 versus month.

of the dynamics is zero, which can thus be interpreted as a radiatively-driven cooling.

We tested the sensitivity of Eq. (1) to the potential errors in derived dynamic trends in SH February and NH February and March as discussed previously. Notice that the SH February radiative cooling should not be smaller than that in March and the NH February and March radiative cooling should not be larger than those in May and April. We thus simply substitute SH February radiative cooling with that in March, and substitute the NH February and March radiative cooling with those in May and April, and derive the dynamic trend as

the difference between the total and radiative components in these months. By applying such corrections that have a magnitude of about $\pm 0.1 \mathrm{~K} /$ decade, we obtain a tropical radiative cooling of $-0.19 \mathrm{~K} /$ decade with $r=-0.95$. Also notice that the correction of the errors in SH February and NH February and March slightly reduces the seasonal dependence of mean radiative trends in these months.

In this study, the eddy heat flux from the NCEP/NCAR reanalysis is used to represent the strength of the BDC. The NCEP/NCAR reanalysis eddy heat flux trend is reliable 


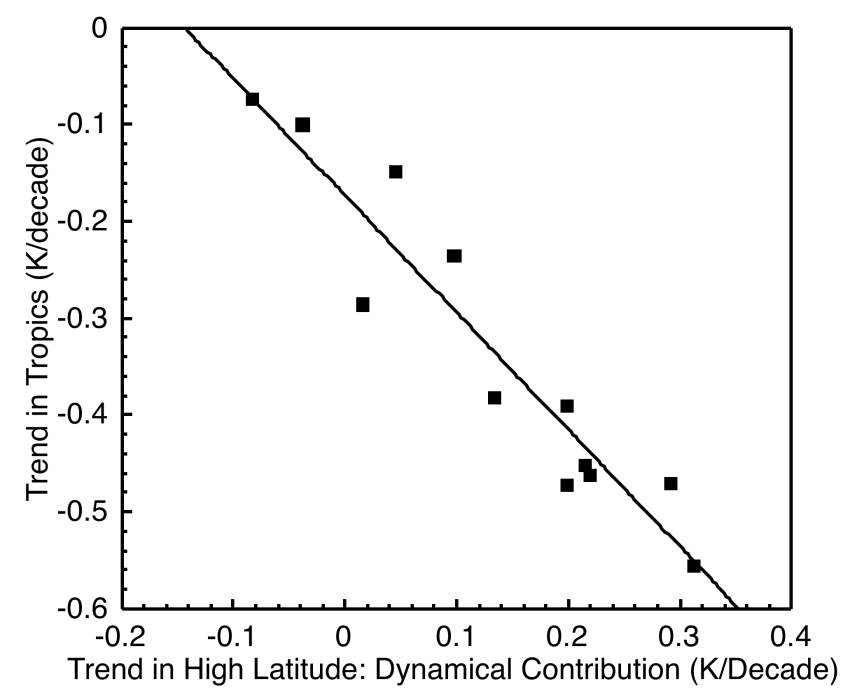

Fig. 11. MSU observed $T_{4}$ rends in tropics $\left(20^{\circ} \mathrm{N}-20^{\circ} \mathrm{S}\right)$ versus dynamically induced $T_{4}$ trends in high latitudes $\left(40^{\circ} \mathrm{N}-82.5^{\circ} \mathrm{N}\right.$ and $40^{\circ} \mathrm{S}-82.5^{\circ} \mathrm{S}$ ) for 12 months of the year for 1980-2008.

because of the following reasons. First, the derived dynamic trends in the high latitudes and their seasonal dependence are largely consistent with the trends in observed $T_{4}$ and ozone as discussed. In particular, the derived dynamic trends are near-zero in the summer seasons (except in February for the $\mathrm{SH})$ as expected. Second, the seasonal dependences of the derived high-latitude radiative trends can well be interpreted in terms of the ozone trends and the solar illumination. Third, the trends in the NCEP/NCAR reanalysis eddy heat flux do have biases in the February for the SH and in February and March for the NH. But such biases do not affect our conclusions and can be corrected.

In order to further examine the reliability of the use of the NCEP/NCAR reanalysis, we compared the results using NCEP/NCAR versus those using ERA-40 for 1980-2001 when the ERA-40 reanalysis is available. The derived dynamic trends based on the two reanalyses agree very well in the $\mathrm{NH}$ while the differences are significant in the SH. The close agreement between the NCEP/NCAR reanalysis and the MSU observations in the SH high latitudes in terms of stratospheric temperature trend patterns ( $\mathrm{Hu}$ and $\mathrm{Fu}, 2009$; Lin et al., 2009) lends confidence to the NCEP/NCAR reanalysis eddy heat flux trend in SH. Furthermore the derived SH dynamic trends based on the independent analysis that does not use the reanalysis data agree with those using the NCEP/NCAR reanalysis (Fu et al., 2009).

In summary, the NCEP/NCAR reanalysis eddy heat flux trend used in this study is reliable and robust.

Although the RSS MSU data are used, consistent results are obtained by using the MSU $T_{4}$ data from the University of Alabama at Huntsville (UAH) team (Christy et al., 2003). Using the UAH data (version 5.1), the $T_{4}$ trend in the

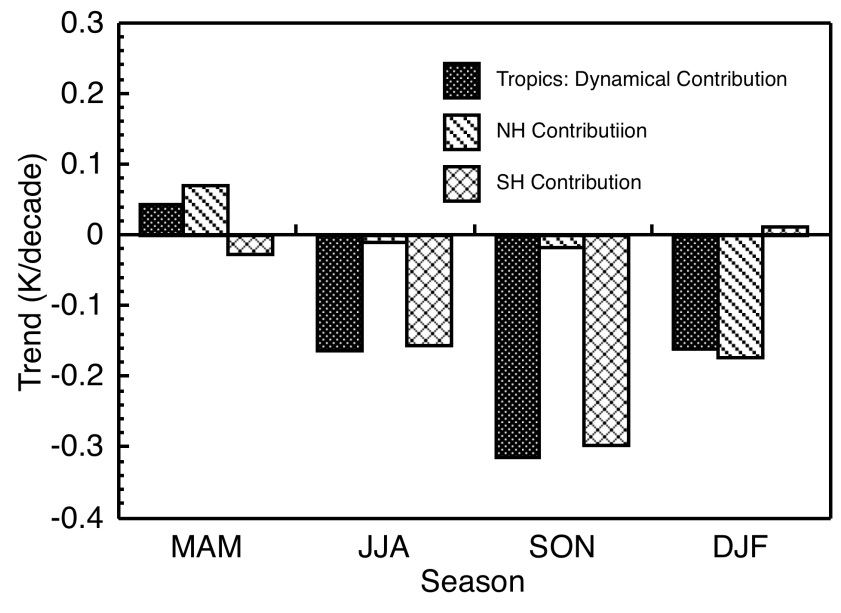

Fig. 12. MSU lower-stratospheric temperature $\left(T_{4}\right)$ trends due to the changes in the BDC in tropics $\left(20^{\circ} \mathrm{N}-20^{\circ} \mathrm{S}\right)$ and its contribution from the $\mathrm{NH}$ and $\mathrm{SH}$ in four seasons for 1980-2008.

tropics due to the direct radiative effects is $-0.21 \mathrm{~K} /$ decade $(r=-0.95)$ for 1980-2008, which also indicates that the $\mathrm{BDC}$ is strengthening in NH summer, fall, and winter but weakening in $\mathrm{NH}$ spring. But the estimated tropical radiative cooling of $-0.21 \mathrm{~K} /$ decade using the UAH data is insensitive to the adjustments in SH February and NH February and March radiative coolings.

Therefore we conclude that our estimated radiative $T_{4}$ trend in tropics is about $-0.19 \mathrm{~K} /$ decade with an uncertainty of $\pm 0.02 \mathrm{~K} / \mathrm{decade}$. Using the trend of $-0.19 \mathrm{~K} / \mathrm{decade}$ as a reference level, Fig. 1 shows that the BDC is becoming stronger in $\mathrm{NH}$ summer, fall, and winter but weakening in $\mathrm{NH}$ spring.

\section{Discussion and conclusions}

GCMs with good representations of the stratospheric processes suggest that the BDC is expected to intensify throughout the year in response to increasing greenhouse gas concentrations and ozone depletion (e.g., Butchart et al., 2006; Li et al., 2008). Using Eq. (1), we derived the tropical MSU $T_{4}$ trend due to the change of the BDC as well as the contribution from each hemisphere. The mean results for four seasons are shown in Fig. 12. The observations reveal the dynamically-induced cooling related to the strengthening of the BDC in JJA, SON, and DJF, in agreement with the model results. But the observations also show a dynamic warming in MAM, indicating a weakening of the BDC in that season, which contrasts with published models. Furthermore, Fig. 12 suggests that the change of the BDC in the last three decades in JJA and SON is dominated by the SH, while the change in DJF and MAM is related to the NH. The change in the annual mean BDC is caused primarily by changes in the $\mathrm{SH}$ cell. 

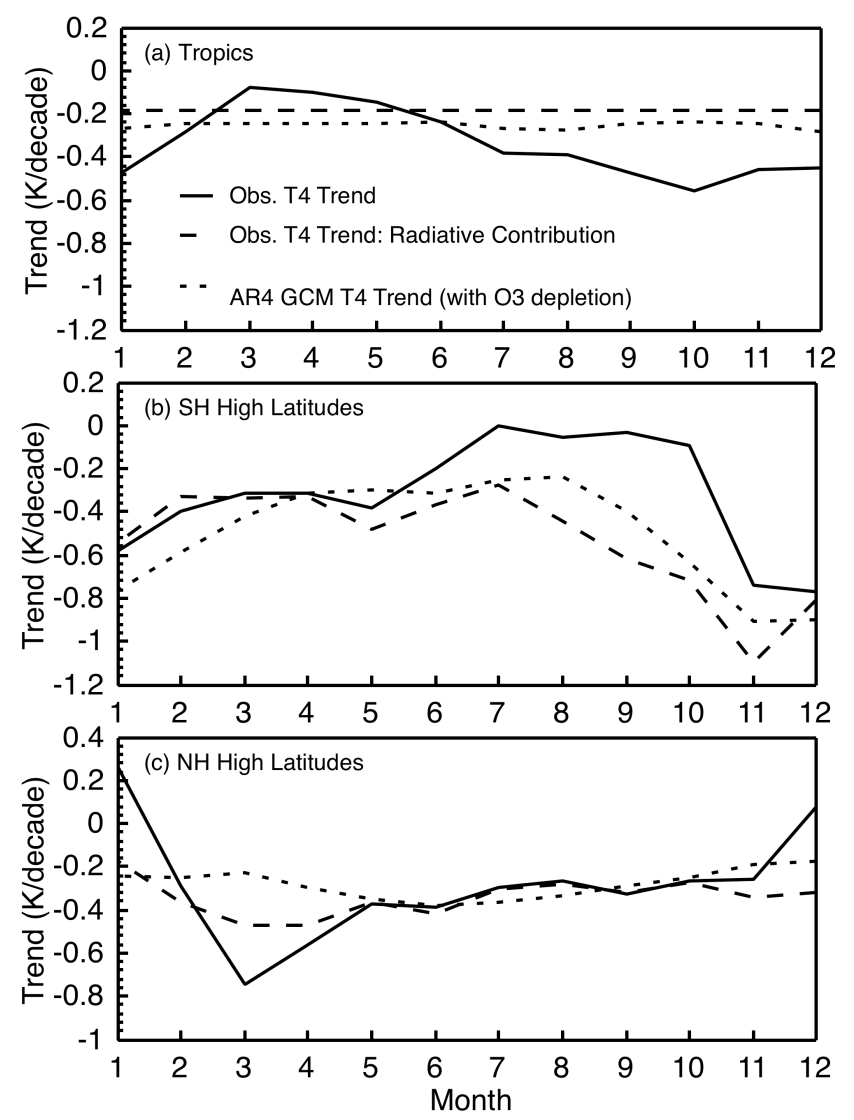

Fig. 13. Compariosn of AR4 GCM simulated $T_{4}$ trends with observations for 12 months of the year for 1980-2008 over (a) tropics, (b) Southern Hemisphere high latitudes, and (c) Northern Hemisphere high latitudes. The solid and dotted lines are the $T_{4}$ trends from MSU observations and GCM simulations, respectively. The dashed lines are radiatively induced $T_{4}$ trends as derived from observations.

The coupled atmosphere-ocean climate models used in the IPCC AR4 generally do not have well-represented stratospheres so that the change of the BDC is unlikely to be captured (Sigmond et al., 2008; LFSW2009). Instead the simulated $T_{4}$ trends in the past 30 years from these models closely follow the radiatively induced $T_{4}$ trends as derived from observations (Fig. 13). Also note that the annual mean total $T_{4}$ trends from the IPCC AR4 GCMs are $-0.25 \mathrm{~K} /$ decade over tropics, $-0.28 \mathrm{~K} /$ decade over $\mathrm{NH}$ high latitudes, and $-0.50 \mathrm{~K} /$ decade over SH high latitudes, as compared with the derived radiative contributions of $-0.19,-0.34$, and $-0.53 \mathrm{~K} /$ decade, respectively, from observations. Such overall agreement lends confidence in derived radiatively induced $T_{4}$ trends from both GCMs and our observational analyses. Figure 13(b) also suggests that the IPCC AR4 models may underestimate the ozone-depletion induced radiative cooling in SH spring but overestimate it in SH summer and early fall. Also note that the observed Arctic total cooling in March far exceeds that expected from the IPCC models despite their consideration of ozone losses.
Rosenlof and Reid (2008) recently analyzed the long-term trends in tropical lower-stratospheric temperatures observed by radiosondes. They found a significant anti-correlation over the tropical western Pacific Ocean between the lowerstratospheric temperatures and SST anomalies. It was suggested that tropical convection may be the link between the ocean and the stratosphere, and the increased stratospheric cooling may be an indication of strengthening tropical convection due to the SST increase. The idea of local forcing is consistent with the analysis by Kerr-Munslow and Norton (2006) who showed that tropical lower-stratospheric upwelling can be modulated by the upward flux of equatorial planetary wave activity. Deckert and Dameris (2008) suggested that this flux may be increasing as tropical SSTs rise and the latent heat release increases. The close coupling between the tropics and high latitudes in the decadal variations of the lower-stratospheric temperatures shown in this study, however, seem to indicate that enhanced tropical lower-stratospheric cooling is dominated by the strengthening of the BDC driven by an increase in extratropical wave forcing instead of a local one. One plausible interpretation of the observational results by Rosenlof and Reid (2008) is a mechanism linking changes in tropical SST to modulation of extra-tropical wave activity through changes in the meridional temperature gradient. It should be noted that our analysis cannot explicitly identify nor totally exclude the possible impact of the tropical wave forcing, if the changes associated with such forcing have small seasonal dependence or they have the same seasonal dependence as the changes associated with extratropical wave forcing.

This study examines the seasonality of the tropical lowerstratospheric temperature trend, and suggests that this is largely driven by changes in the BDC. We also estimate the lower stratospheric cooling in the tropics due to the direct radiative effect which is estimated to be $-0.19 \mathrm{~K} /$ decade for 1980-2008. Using the tropical lower-stratospheric temperature trends as an indicator of the change in the BDC, we find that the strengthening of the BDC since 1980 occurs in JuneNovember related to the SH cell and in December-February related to the $\mathrm{NH}$ cell. We also find the BDC is weakening in March-May because of a weakening of the northern cell.

The present study provides observational evidence that decadal variations in the tropical lower-stratospheric temperatures and those in high latitudes are strongly coupled through the change of the BDC. Other studies also suggest such couplings on the seasonal and inter-annual time scales (e.g., Yulaeva et al., 1994; Salby and Callaghan, 2002; Chae and Sherwood, 2007; Ueyama and Wallace 2009). Note the downward control principle predicting that on time scales longer than the radiative relaxation time, the response to wave breaking should be local in the latitude domain (Holton et al., 1995). Thus the key question that needs to be addressed is whether the change in wave forcing is consistent with a change in the BDC that is broad in latitude. Another outstanding issue is that a recent observational study which 
examined the stratospheric air age (Engel et al., 2009) indicates a slight weakening of the annual mean BDC in last three decades, which contrasts with our results that suggests a strengthening of the annual mean BDC. Further research is required to reconcile these results by carefully considering the observational uncertainties.

Acknowledgements. We thank J. M. Wallace, K. H. Rosenlof and R. Ueyama for useful discussions. This work is supported by NOAA Grant NA08OAR4310725, National Basic Research Program of China (2010CB428604), and NASA Grants NNX08AG91G \& NNX08AF66G.

Edited by: W. Lahoz

\section{References}

Andrews, D. G., Holton, J. R., and Leovy, C. B.: Middle atmosphere dynamics, Academic Press, Orlando, USA, 489 pp., 1987.

Butchart, N., Scaife, A. A., Bourqui, M., de Grandpre, J., Hare, S. H. E., Kettleborough, J., Langematz, U., Manzini, E., Sassi, F., Shibata, K., Shindell, D., and Sigmond M.: Simulations of anthropogenic change in the strength of the Brewer-Dobson circulation, Clim. Dynam., 27, 727-741, 2006.

Chae, H. C. and Sherwood, S. C.: Annual temperature cycle of the tropical tropopause: A simple model study, J. Geophys. Res., 112, D19111, doi:10.1029/2006JD007956, 2007.

Christy, J. R., Spencer, R. W., Norris, W. B., Braswell, W. D., and Parker, D. E.: Error estimates of version 5.0 of MSU-AMSU bulk atmospheric temperatures, J. Atmos. Ocean. Tech., 20, 613-629, 2003.

Deckert, R. and Dameris, M.: Higher tropical SSTs strengthen the tropical upwelling via deep convection, Geophys. Res. Lett., 35, L10813, doi:10.1029/2008GL033719, 2008.

Eichelberger, S. J. and Hartmann, D. L.: Changes in the strength of the Brewer-Dobson Circulation in a simple AGCM, Geophys. Res. Lett., 32, L15807, doi:10.1029/2005GL022924, 2005.

Engel, A., Mobius, T., Bonisch, H., et al.: Age of stratospheric air unchanged within uncertainties over the past 30 years, Nature Geosci., 2, 28-31, 2009.

$\mathrm{Fu}$, Q. and Johanson, C. M.: Satellite-derived vertical dependence of tropical tropospheric temperature trends, Geophys. Res. Lett., 32, L10703, doi:10.1029/2004GL022266, 2005.

Fu, Q., Solomon, S., and Lin, P.: On the seasonal dependence of tropical lower-stratospheric temperature trends, Atmos. Chem. Phys. Discuss., 9, 21819-21846, 2009,

http://www.atmos-chem-phys-discuss.net/9/21819/2009/.

Haklander, A. J., Siegmund, P. C., Sigmond, M., and Kelder, H. M.: How does the northern-winter wave driving of the Brewer-Dobson circulation increase in an enhancedCO2 climate simulation?, Geophys. Res. Lett., 35, L07702, doi:10.1029/2007GL033054, 2008.

Haynes, P. H., Marks, C. J., McIntyre, M. E., Shepherd, T. G., and Shine, K. P.: On the "downward control" of extratropical diabatic circulations by eddy-induced mean zonal forces, J. Atmos. Sci., 48, 651-678, 1991.

Holton, J. R., Haynes, P. H., McIntyre, M. E., Douglass, A. R., Rood, R. B., and Pfister, L.: Stratosphere-troposphere exchange, Rev. Geophys., 33, 403-439, 1995.
Hu, Y. and Tung, K. K.: Interannual and decadal variations of planetary wave activity, stratospheric cooling, and Northern Hemisphere annual mode, J. Climate, 15, 1659-1673, 2002.

$\mathrm{Hu}$, Y. and Fu, Q.: Stratospheric warming in Southern Hemisphere high latitudes since 1979, Atmos. Chem. Phys., 9, 4329-4340, 2009, http://www.atmos-chem-phys.net/9/4329/2009/.

Johanson, C. M. and Fu, Q.: Antarctic atmospheric temperature trend patterns from satellite observations, Geophys. Res. Lett., 34, L12703, doi:10.1029/2006GL029108, 2007.

Kalnay, E., Kanamitsu, M., Kistler, R., Collins, W., Deaven, D., Gandin, L., Iredell, M., Saha, S., White, C., Woollen, J., Zhu, Y., Chelliah, M., Ebisuzaki, W., Higgins, W., Janowiak, J., Mo, K. C., Ropelewski, C., Wang, J., Leetmaa, A., Reynolds, R., Jenne, P., and Joseph, D.: The NCEP/NCAR 40-year reanalysis project, B. Am. Meteorol. Soc., 77, 437-471, 1996.

Kerr-Munslow, A. M. and Norton, W. A.: Tropical wave driving of the annual cycle in tropical tropopause temperatures. Part 1: ECMWF analyses, J. Atmos. Sci., 63, 1410-1419, 2006.

Li, F., Austin, J., and Wilson, J.: The strength of the Brewer-Dobson circulation in a changing climate: a coupled chemistry model simulation, J. Climate, 21, 40-57, 2008.

Lin, P., Fu, Q., Solomon, S. and Wallace, J. M.: Temperature trend patterns in Southern Hemisphere high latitudes: novel indicators of stratospheric changes, J. Climate, 22, 6325++6341, 2009.

Mears, C. A. and Wentz, F. J.: Construction of the Remote Sensing Systems V3.2 Atmospheric Temperature Records from the MSU and AMSU Microwave Sounders, J. Atmos. Oceanic Technol., 26, 1040-1056, 2009.

Meehl, G. A., Covey, C., McAveney, B., Latif, M., and Stouffer, R. J.: Overview of the coupled model intercomparison project, B. Am. Meteorol. Soc., 86, 89-93, 2005.

Newman, P. A., Nash, E. R., and Rosenfield, J. E.: What controls the temperature of the Arctic stratosphere during the spring? J. Geophys. Res., 106D17, 19999-20010, 2001.

Ramaswamy, V., Schwarzkopf, M. D., and Randel, W. J.: Fingerprint of ozone depletion in the spatial and temporal pattern of recent lower-stratospheric cooling, Nature, 382, 616-618, 1996.

Ramaswamy, V., Schwarzkopf, M. D., Randel, W. J., Santer, B. D., Soden, B. J., and Stenchikov, G.: Anthropogenic and natural influences in the evolution of lower stratospheric cooling, Science, 311, 1138-1141, 2006.

Randel, W. J., Wu, F., Nedoluha, G., Vomel, H., and Forster, P.: Decreases in stratospheric water vapor since 2001: Links to changes in the tropical tropopause and the Brewer-Dobson circulation, J. Geophys. Res., 111, D12312, doi:10.1029/2005JD006744, 2006.

Rind, D., Lerner, J., and McLinden, C.: Changes of trace distributions in the doubled CO2 climate, J. Geophys. Res., 106, 2806128080, 2001.

Rosenlof, K. H. and Reid, G. C.: Trends in the temperature and water vapor content of the tropical lower stratopshere: Sea surface connection, J. Geophys. Res., 113, D06107, doi:10.1029/2007JD009109, 2008.

Salby, M. L. and Callaghan, P. F.: Interannual changes of the stratospheric circulation: Relationship to ozone and tropospheric structure, J. Climate, 15, 3673-3685, 2002.

Shine, K. P., Bourqui, M. S., Forster, P. M. F., et al.: A comparison of model-simulated trends in stratospheric temperatures, Q. J. Roy. Meteor. Soc., 129, 1565-1588, 2003.

Sigmond, M., Scinocca, J. F., and Kushner P. J.: Impact of 
the stratosphere on tropospheric climate change, Geophys. Res. Lett., 35, L12706, doi:10.1029/2008GL033573, 2008.

Stolarski, R. S., Douglass, A. R., Steenrod, S., and Pawson, S.: Trends in stratospheric ozone: Lessons learned from a 3D chemical transport model, J. Atmos. Sci., 63, 1028-1041, 2006.

Thompson, D. W. J. and Solomon, S.: Understanding recent stratospheric climate change, J. Climate, 22, 1934-1943, 2009.
Ueyama, R. and Wallace, J. M.: To what extent does high-latitude planetary wave breaking drive tropical upwelling in the BrewerDobson circulation, J. Atmos. Sci., submitted, 2009.

Yulaeva, E., Holton, J. R., and Wallace, J. M.: On the cause of the annual cycle in tropical lower-stratospheric temperatures, J. Atmos. Sci., 51, 169-174, 1994. 